\begin{tabular}{|c|c|c|}
\hline U N I V & $\begin{array}{l}\text { A N A L E } \\
\text { MARIAE C } \\
\text { BLIN - POI }\end{array}$ & \\
\hline VOL. XXXVIII & SECTIO FF & $1-2020$ \\
\hline
\end{tabular}

ISSN: 0239-426X • e-ISSN: 2449-853X • Licence: CC-BY 4.0 • DOI: 10.17951/ff.2020.38.1.187-198

\title{
Trust and Suspicion: Gabriel Josipovici on Shakespeare and Modernity*
}

\author{
Ufność i wątpienie: Gabriel Josipovici o Szekspirze i nowoczesności
}

\author{
MAGDALENA SAWA \\ John Paul II Catholic University of Lublin, Poland \\ ORCID ID: http://orcid.org/0000-0002-0410-1832 \\ e-mail: sawka@kul.lublin.pl
}

\begin{abstract}
The aim of this paper is to present Gabriel Josipovici's seminal publication On Trust: Art and the Temptation of Suspicion (1999) as a valuable contribution to the contemporary affective debate and the post-postmodernist undoubting perspective. An eminent British novelist, playwright and critic, Josipovici attempts in his study to characterise pre-modern cultures and the modern world in terms of contrastive emotional attitudes of trust and suspicion. This article seeks to present the part of Josipovici's extended discussion which pertains to the crucial phase in modern history when the feeling of suspicion began to gain intensity; hence the concentration on the moment of transition, the advent of modernity in the Renaissance and the way Shakespeare's plays thematise the tension between trust and suspicion in the face of the tenets of humanism and Protestantism. Additionally, the presentation of the central idea of On Trust is aided with references to Josipovici's other publications such as Writing and the Body (1982), The Book of God (1988), What Ever Happened to Modernism? (2010) and Hamlet: Fold on Fold (2016) in order to show the author's concern with the interplay in culture of trust and suspicion as informing his entire critical thought.
\end{abstract}

* The volume is funded from the budget of the Institute of Polish Studies of Maria Curie-Skłodowska University, from the funds of the Minister of Science and Higher Education for activities promoting science (contract no. 615/P-DUN/2019) and under the "Support for Academic Journals" programme (contract no. 333/WCN/2019/1 of 28 August 2019). Publisher: Wydawnictwo UMCS.

Contact details of the author: The John Paul II Catholic University of Lublin, 14 Racławickie Av., 20-950, Lublin, Poland, phone: +48 814454101. 
Keywords: Gabriel Josipovici, trust, suspicion, Shakespeare, modernity

\begin{abstract}
Abstrakt. Celem artykułu jest ukazanie pracy Gabriela Josipovici zatytułowanej On Trust: Art and the Temptation of Suspicion (1999) jako cennego wkładu we współczesne rozważania nad afektem oraz kształtowaniem się post-postmodernistycznej postawy odrzucającej wątpienie. Wybitny brytyjski pisarz, dramaturg i krytyk Josipovici podejmuje próbę charakterystyki kultur przednowoczesnych oraz świata nowoczesnego za pomocą dwóch kontrastowych postaw emocjonalnych: ufności i wątpienia. Artykuł przedstawia tę część rozważań autora, która dotyczy istotnego momentu w historii świata, kiedy to uczucie wątpienia zaczyna dominować w kulturze. Stąd koncentracja na wyłanianiu się nowoczesności w renesansie, znajdujące odzwierciedlenie w utworach Szekspira, które wskazują na napięcie między ufnością i wątpieniem tworzące się w kontekście humanizmu i protestantyzmu. Próbie rekonstrukcji myśli przewodniej On Trust towarzyszą odniesienia do innych utworów Gabriela Josipovici, takich jak: Writing and the Body (1982), The Book of God (1988), What Ever Happened to Modernism? (2010) i Hamlet: Fold on Fold (2016). Dzięki odwołaniom do innych prac Josipovici udowodniono, że perspektywa ufności i wątpienia jest stale obecna w myśli krytycznej autora.
\end{abstract}

Słowa kluczowe: Gabriel Josipovici, ufność, wątpienie, Szekspir, nowoczesność

In his 1941 publication Sensibility and History: How to Reconstitute the Emotional Life of the Past, Lucien Febvre expressed his strong belief in the importance of emotions: "But the history of hate, the history of fear, the history of cruelty, the history of love, for goodness' sake stop bothering us with that empty talk! But the subject of such empty talk [...] will tomorrow have finally made our universe into a stinking pit of corpses" (1973, p. 26). Barbara H. Rosenwein calls Febvre "the prophet crying in the wilderness, the man who saw the light but had few followers" (2002, p. 822) and she does so not only because of the atrocities of World War II that ensued but also due to the evident dearth of scholarly interest in emotions at that time. ${ }^{1}$ Half a century later the situation altered drastically. Since the 1990s the study of affect ${ }^{2}$ has been a major growth area in such disciplines as psychology, psychoanalysis, neurobiology, social studies and the humanities, and has generated a number of significant works. ${ }^{3}$ In the current upsurge in research

${ }^{1}$ Paradoxically, while Febvre's emotive stance about the need for research in emotions was inspired by the criminal warfare, Nazi ideology as well as the experience of the Holocaust led, as Johannes Lang argues (2018), to the neglect of the studies of human affectivity in the post-war period. Contingent on biological processes, emotions must have been kept at bay and away from the humanities and social sciences.

2 Although Brian Massumi makes a clear distinction between affect and emotion in his seminal study Parables for the Virtual (2002), he admits therein that those two terms are frequently used synonymously in the contemporary discourse. Such is also the case with the present study whose general character makes Massumi's nuanced differentiation irrelevant.

${ }^{3}$ Due to the proliferation of the studies of affect and the limited space of the introduction, I include here only a very preliminary list of publications which early-stage researchers might find of in- 
investigating affective phenomena Febvre's call for a historical perspective on emotions as well as an emotional perspective in history was heard in, among others, Peter N. Stearns' Jealousy: The Evolution of An Emotion in American History (1989), Peter N. Stearns and Jan Lewis' An Emotional History of the US (1998) or Michael Laffan and Max Weiss' Facing Fear: The History of an Emotion in Global Perspective (1994).

Gabriel Josipovici's publication On Trust: Art and the Temptation of Suspicion (1999) is another important contribution to the contemporary affective debate conveyed from the perspective of literary history. An eminent British novelist, playwright and critic, Josipovici attempts in his study to characterise culture in terms of contrastive emotional attitudes of trust and suspicion. His intense concentration on literature makes his study a historical survey of how suspicion has come to dominate modern creative thinking. Josipovici's aim is to alert us to the fact that "suspicion itself has a history [...] [and] by tracing that history, by uncovering its genealogy, we may be able to understand what it is that it supplants and why, once it appears, it seems so irresistible" $(1999$, p. 24). The main objective of the present study is to sketch Josipovici's dualistic and dynamic vision of pre-modern cultures defined by the prevalence of trust and the modern world gradually falling under the dominion of suspicion. Apart from the general outline, this article seeks to present the part of Josipovici's extended discussion which pertains to the crucial phase in modern history when the feeling of suspicion began to gain intensity. Of particular interest here is the moment of transition, the advent of modernity in the Renaissance and the way Shakespeare's plays thematise the tension between trust and suspicion in the face of the tenets of Humanism and Protestantism.

The reason for the concentration on Shakespeare's texts in place of Josipovici's insightful discussions of Dante, Wordsworth, Proust, Kafka and Beckett, also included in On Trust, is twofold. Firstly, when an earlier version of this article was presented at the 2017 ESRA Annual Congress on "Shakespeare and European Theatrical Cultures: An Atomizing Text and Stage," the popularity of Josipovici's critical contribution to the studies of Shakespeare's oeuvre was not acknowledged by the participants of my session. Secondly, Josipovici's vigorous scholarly activity in this field has not been given tribute in significant contemporary studies

terest: Keith Oatley and Jennifer Jenkins' Understanding Emotions (1996), Simon Blackburn's Ruling Passions: A Theory of Practical Reasoning (1998), Paul Redding's The Logic of Affect (1999), Paul Goldie's The Emotions: A Philosophical Exploration (2000), Rei Terada's Feeling in Theory: Emotion after the "Death of the Subject" (2001), Teresa Brennan's The Transmission of Affect (2004), Patricia Ticineto Clough and Jean Halley's The Affective Turn: Theorizing the Social (2007). 
of Shakespeare, either of a general or more specialist character. ${ }^{4}$ Due to this gross negligence, it seems worthwhile to popularise, however succinctly, the thought of this singularly perceptive commentator who has much to say about literature and art beyond modernism, with which he is most commonly associated. Additionally, the presentation of the central idea of On Trust is aided with references to Josipovici's other publications such as Writing and the Body (1982), The Book of God (1988), What Ever Happened to Modernism (2010) and Hamlet: Fold on Fold (2016) in order to show the author's concern with the interplay in culture of trust and suspicion as informing his entire critical thought.

In 1950, Nathalie Sarraute published an essay in Les Temps Modernes entitled in English The Age of Suspicion. Derived from Stendhal's remark made in 1832: "The spirit of suspicion has entered the world" (qtd. in Josipovici, 1999, p. 7), her words, as Josipovici rightly notices, proved prophetic in their apt rendering of the condition of our contemporary culture. Other examples of the prevalence of suspicion in the reflection upon the present that Josipovici cites are quite obvious but the conclusions he draws from the examples he gives have become obvious only recently in the context of Lee Konstantinou's (2017) idea of postirony or Robin van den Akker and Timotheus Vermeulen's (2017) notion of metamodernism. He mentions Theodor Adorno's call for mistrust "in the face of all spontaneity, impetuosity, all letting oneself go" (1974, p. 34) and Paul Ricoeur's phrase "hermeneutics of suspicion" used in reference to the works of Marx, Nietzsche and Freud. He devotes also much space to Roland Barthes as "the wittiest and most subtle of the modern French masters of suspicion" (Josipovici, 1999, p. 12) to show his concern with demythologising the novel. Since, however, with time Barthes' refreshing remarks as well as "the hard-won insights and ironical barbs" (1999, p. 12) of the earlier thinkers began to be conceived of as "a method or an orthodoxy" (1999, p. 12), the sole recommendation for both the reader and the writer that postmodernism can be said to produce is to celebrate suspicion:

Let us accept that all making is tainted and corrupt, that there is no meaning to life or art [...] and let us rejoice in this rather than lamenting it, and amuse ourselves with it while we can, playfully unmasking false transcendence and bad metaphysics, whether in the making of artefacts or in the writing of criticism. (Josipovici, 1999, pp. 22-23)

${ }^{4}$ We will find no mention of Josipovici's critical comments in, for example, Michael Dobson and Stanley Wells' The Oxford Companion to Shakespeare (2001), Norman Sanders' Othello (2003), Alexander Leggatt's Shakespeare's Tragedies (2005), Emma Smith's The Cambridge Introduction to Shakespeare (2007), or Paul Megna, Brío Phillips and R.S. White's Hamlet and Emotions (2019). 
The problem with today's world, as Josipovici observes, is that while trust without suspicion generates a false and meretricious art, suspicion without trust makes art superficial and meaningless. Josipovici wants to avoid both, hence his deep attraction to modernist writers who, though beleaguered with doubt and hesitance, were still ready to accept the fragmentariness of form as a vehicle for thought and appreciate our inevitable immersion in time and language. Since Josipovici's reaction to the postmodernist offer is definite: "it fails to satisfy me" (1999, p. 23), ${ }^{5}$ his aim in On Trust is to trace the history of suspicion, to expose reasons for its emergence as well as to locate the source of its overwhelming power.

Both in On Trust and later in What Ever Happened to Modernism? Jospovici evinces intense longing for the lost order of the ancient world and the culture of trust permeated by "a sense of life in all its goodness, happiness, abundance; and death as finality, which must be accepted as part of that abundance" (1999, p. 35). Following Schiller, he bemoans the contrast between civilisation and nature which underlies modern thinking ${ }^{6}$ while being completely absent from the non-sentimental perspective of ancient Greeks. This attitude lends Greek literature peculiar lightness, which, however, should not be mistaken for facileness. Josipovici's evocation of Friedrich Nietzsche's words: "The Greeks were superficial out of profundity" (1974, p. 9) suggests the opposite. The apparent ruthlessness or callousness of Homer's descriptions of fight, pain or death should be read as an element of what Josipovici calls "the double vision" in which human beings "are not alone but part of a larger rhythm" (Josipovici, 1999, p. 27), safely installed in "the substantial categories of state, family and destiny" (1999, p. 40). Josipovici argues that by trying to psychologise Greek tragedy we do great damage to this art by seeking self-reflexive gravity where there is none. As Josipovici observes, the prescribed reaction to Greek drama is enclosed in Lawrence Langer's (1995) comment on one of Leo Haas's disquieting images, Expecting the Worst: "Look and see, and, seeing, grieve" (1999, p. 58).

Homeric poetry and the Hebrew Bible are construed by Josipovici as closely related. Following its Greek counterpart, the biblical text aims to "stress the notion of trust, a confidence in God's ultimate beneficence and in the helping power of laws and traditions" (Josipovici, 1999, p. 44). Josipovici explains further that in the biblical world "the good man never gets to know the mystery of the kingdom of God; rather he learns to walk in the way of the Lord" (1999, p. 44). This trust

5 Josipovici's uncommon spelling of post-Modernism immediately signals his sympathies.

${ }^{6}$ See also Bruno Latour We Have Never Been Modern (1991) where the central idea explored by the author is that what lies at the heart of modernity and is wrongly construed as its chief success is the separation of nature and culture. 
in a universal rhythm becomes apparent in formal qualities of the text: in stylistic parataxis, in poetical parallelism and in the variation of narrative themes. As Josipovici demonstrates in his monumental study of the Bible The Book of God, it is not the logical accountability that matters in the biblical reality but mystery and the acceptance of our limitations. "[I]n the whole book [...]," he explains, "the issue of causality and responsibility, in God, in man, will be raised again and again, but will never be settled in such a way that we can shut the book and say: now I know" (1988, pp. 22-23). The same appears to be true about Greek literature. What must inevitably lead to tragedy is the situation when men crave true knowledge (self-knowledge in particular) or grow convinced that they are in total control. The internal struggle within oneself of conflicting factions has become the predominant theme of modern literature whereby the fact that it is not the only way of conceiving of the self has been obliterated. Consequently, Plato and Christianity as the original sources of "a whole new world of inwardness" (Josipovici, 1999, p. 47) become objects of Josipovici's criticism as allies of suspicion rather than trust.

Shakespeare's career came at the time when a great shift in human thinking was taking place and the secular modern world was emerging. The Renaissance is commonly and, according to Josipovici, over-optimistically viewed as a period in which " $\mathrm{t}] \mathrm{the}$ repressive tyranny of the Church was being destroyed and Protestantism had got rid of old superstitions while Humanism gave the individual a new freedom to express himself" (Josipovici, 2010, p. 39). This cardinal shift in mindset, which can be briefly encapsulated as a transition from the age of cult to the age of an individual (p. 17), was eagerly thematised by the art of this period. Albrecht Dürer's pair of engravings St Jerome in His Study and Melancholia I is viewed by Josipovici as embodying the ills of the newly materialising reality: the loss of trust and order on the one hand and the feeling of suspicion and despair as a natural consequence of the privation on the other. In his enquiry into Rabelais' Gargantua Josipovici concentrates on the character of Picrochole. Rather than a tyrant with an insatiable will to power, he is presented as "a figure of the artist in his new circumstances, cut off from tradition and without either the muses or the rules of the Christian iconography to guide him as they guided Homer and the medieval artist, and having to fall back on his imagination" (Josipovici, 2010, pp. 27-28). The opening of Don Quixote, in turn, is meant to uncover "the purely arbitrary and private nature" (Josipovici, 2010, p. 28) of Cervantes' writing. Deprived of both authority and access to the truth, Cervantes proclaims himself as "the spokesman for a new community of solitary individuals" (p. 29). In a similar way, Shakespeare's most mature plays seem to be responding to the loss of the world of trust and its being replaced by a pursuit of meaning, reflexive interiority, as well as distrust of time and language. 
Josipovici's discussion of Shakespeare's oeuvre begins with Richard II in which the main focus is identified as the presentation of the vanishing world of order and trust. The critic identifies the composition of the play as the moment in Shakespeare's career when he realises that he is writing in a world in which trust has begun to yield to the lure of suspicion. This political drama opens with a preparation for a judicial duel in which Mowbray and Bolingbroke are about to prove the truth of their claims "with their bodies, on the body of their opponent" (Josipovici, 1999, p. 95). The emphasis on the fact that it is through the body of the two men that the issue is going to be resolved is meant to prepare us for Josipovici's argument that the initial scene is a variation of the ritual of the ordeal. This barbaric practice, as we would be inclined to call it nowadays, was a public spectacle whereby God's judgment was conferred. While its popularity in the Middle Ages was enormous, it began to weaken in the $12^{\text {th }}$ century due to the changes in the organisation of communities as well as the new concern with the law. Set much later because in the late $14^{\text {th }}$ century Richard II exposes Shakespeare's great ability to "condense and concentrate in one powerful dramatic incident the ethos of a whole culture" (Josipovici, 1999, p. 97). As we know, the duel never takes place hindered by the king's intervention. Reasons for the stoppage can be manifold but they are never explicitly stated in the play. The explanation that Josipovici proffers is that the scene exposes Richard's lack of trust in the process that tradition has dictated. In Peter Brown's study Society and the Supernatural: A Medieval Change, with the aid of which Josipovici builds his argument, the decline of the ordeal is related to the shift from consensus to authority, which in turn problematises the relation between subjectivity and objectivity, inner and outer, not conceived of as strict oppositions by the early Middle Ages. The moment Richard throws his warder down, the consensus breaks and the king begins to exercise arbitrary authority. His hesitation about how to punish Mowbray and Bolingbroke points to his ambiguous stance about his position as at once a God's vicar and a powerful individual. Equivocating between these two options Richard becomes a witness not only to the crumbling of his own personal reality but also to the disintegration of the meaning of the contemporary world.

Inasmuch as Richard II reveals Shakespeare's awareness of the epochal shift towards doubt and suspicion, Midsummer Night's Dream seeks to revive the discarded tradition. Josipovici views this buoyant comedy as a play in which Shakespeare demonstrates full understanding of what belonging to a craft tradition entailed; it is the dramatist's attempt at imitating the lightness and ambiguity of ancient texts: "The play is so difficult to talk about precisely because its perfection feels neither frozen nor imposed but is inherent in a gathering rhythm which unleashes potential without disintegrating in the process" (1999, p. 103). By virtue of its dynamic 
and erratic nature, Midsummer Night's Dream provokes in the characters as well as commentators a wild pursuit of a bottom, "a base or core" $(1999$, p. 106). If the play can be said to uncover any meaning or message, as Josipovici argues, it is when Bottom relates his dream:

I have had a most rare vision. [...] The eye of man hath not heard, the ear of man hath not seen, man's hand is not able to taste, his tongue to conceive, nor his heart to report what my dream was. I will get Peter Quince to write a ballet of this dream. It shall be called "Bottom's dream", because it hath no bottom. (Harbage [ed.], 1977, pp. 203-214)

The overly parodic treatment of St Paul's teaching in Bottom's speech stresses the fact that rather than the revelation of the truth (as it happened to Christ's disciple on the road to Damascus), it is the acceptance of the impenetrability of life that is essential for mankind.

While in the final comment on Midsummer Night's Dream Josipovici sees the play as a way of warning us "how crushing and restrictive are both law and subjectivity, and even understanding itself' (1999, p. 107), Hamlet is presented as enabling Shakespeare to take a closer look at the intrusive and penetrating nature of suspicion, specified as compulsive self-questioning. Josipovici derives his method for analysing Hamlet in his book-length study Hamlet, Fold on Fold from Mallarmé's fascination with a fan. As Josipovici explains, this trivial object arrested the poet's attention due to its curiously double nature: "For a fan is not simply vertical when shut and horizontal when open, it allows us to imagine an absolute verticality and an absolute horizontality united in one object so small and light it almost does not exist - the very model of Mallarmé's ideal poem" (2016, p. 11). Accordingly, Josipovici's approach to Hamlet is motivated by the study of the way the play develops horizontally in time and how, while unfolding, it carries vertically in their causal relation all the other moments in the play. By combining the horizontal dimension of unfolding with the vertical dimension of understanding the play clearly relates to Josipovici's study of trust as the acceptance of what time brings and suspicion as the pressing need to understand.

The opening question "Who's there?" becomes, according to Josipovici, the leitmotif of the entire play (2016, p. 15). Claudius and the court are preoccupied mainly with discovering Hamlet's motifs, while Hamlet himself is obsessively engaged in the same endeavour. What baffles both the hero and the audience is that he does not feel comfortable in any role that he assumes or is expected to assume in the course of the play. Severely alienated from the world, he cannot naturally become part of the events occurring around him. ${ }^{7}$ The explanation Josipovici propounds

${ }^{7}$ Further on in On Trust, Josipovici carries out an insightful and moving analysis of Kafka's work and life. His observations about the modernist writer may easily be applied to Hamlet: "the 
for this anxiety-ridden situation is that the world inhabited by Old Hamlet and Old Fortinbras, in which the duty of revenge is well-entrenched and incontestable, is no longer Hamlet's world. For the same reason, he is unable to relate to the characters who belong to his own generation: Leartes, Fortinbras or Horatio. While each of them unquestioningly accepts his role "and plays it to the hilt" (Josipovici, 1999, p. 110), Hamlet perceives their actions as overplaying: "Hamlet, like Kierkegaard, has too strong a sense of tradition not to see that those who pretend or imagine that they are still part of it have failed to see how things have changed, and that as a result everything about them is false" (1999, p. 111).

While Hamlet is commonly considered Shakespeare's most famous play, in the study of the interplay of trust and suspicion in Shakespeare's drama it is Othello that occupies a special place. Josipovici conceives of it as a "copy-book demonstration of what happens when trust and suspicion come into contact" (1999, p. 111). His extensive analysis of the play in Writing and the Body can be viewed as a preliminary stage of argumentation which, however, shows a clear affinity to the central idea of On Trust. Othello is presented in Josipovici's earlier work as an enactment of the struggle between "the culture of story and decorum and that of plot and truth" (1982, p. 53). Following Frye, Josipovici explores the connection between Shakespeare's drama and story-telling, medieval drama and opera, which leads him to the conclusion that as an upholder of "the old, oral, story-like kind of play" (1982, p. 40) Shakespeare stands in opposition to Jonson with his inclination towards "a new, teleologically oriented drama, with an insistence on plot and on the creation of an unbreakable illusion" (1982, p. 40).

Unlike Hamlet, Othello abstains from introspection: "he is what he does and what he can relate" (Josipovici, 1999, p. 111). Compared to an oral story-teller, he is not interested in arguing but in recounting. It is the role of Iago to sum up and explicate the characters of others and it becomes evident in the course of the story that Iago's language gradually infects that of Othello. The Moorish general's suspicious attitude develops as a result of Iago's veiled encouragement to interpret, to get to the bottom of things, to lay bare what Bottom understood should remain covert. The change that Othello portrays is from the conviction that a person is tantamount to the role he plays in the community to the suspicion that this role merely hides "the essential self" (Josipovici. 1999, p. 115). Therefore, Iago is defined by Josipovici as a destroyer while his motive as "the need to bring things to an end,

others seem to find life natural, they appear to be »inside« it, trusting it completely and drawing their strength and their happiness from such trust, while he, for whatever reason, lacks that trust and can only look in on life from the outside with longing and despair" (1999, p. 200). 
to have done with the uncertainty and multiple possibilities of life and arrive at the ultimate »truth « of death and destruction" (1982, p. 48).

Although both Othello and King Lear exemplify the triumph of plotting over story-telling, Josipovici's study of the way Shakespeare explores the complex and dynamic relation between trust and suspicion does not end on this pessimistic note. In On Trust a separate chapter is devoted to Winter's Tale wherein, as Josipovici demonstrates, Shakespeare reverses the trend and makes lightness triumph over gravity.

Against what might be too hastily assumed, Leontes does not move in the play from trust to suspicion. Unable to accept time and whatever modification it may bring, he has always been driven by doubt. Josipovici explains the eruption of Leontes' suspicious fantasies by his fear of change, best exemplified by his fear of fatherhood. He is as much in awe of the unborn child, as he is of Mamillius, his son, whom he asks repeatedly "Are thou my boy?" Leontes' fascination with the idyllic stagnation of Eden, and consequently his behaviour of mistrust towards his wife, friend and son are a result of a more profound questioning of the world, of "a pathological failure to envisage growth and change" (Josipovici, 1999, p. 129). Genuine trust entails the acceptance of uncertainty and difference, whereas the one Leontes thinks of is synonymous with simple-mindedness and naivety. Autolycus aptly defines the term for himself and Leontes when he says: "What a fool Honesty is! And Trust, his sworn brother, a very simple gentleman!" (Harbage [ed.], 1977, pp. 588-589). Interestingly, time is not only the main theme in Winter's Tale but it becomes a character, a palpable creature and thus life itself: "Time here as in the Hebrew scriptures is not so much what is eventually revealed as what unfolds" (Josipovici, 1999, p. 134). The play, as Josipovici tries to convince us, ends in more than a happy ending - there is a wonder as a response to the world once we have relinquished doubting. That is how Leontes reacts to Hermione being supposedly brought back to life by Paulina and his reaction is of the one who has experienced suspicion and suffered its distorting and destructive effects.

Synoptic and condensed, this text can never do full justice to the subtlety on the one hand and extensiveness on the other of Josipovici's examination of cultural processes defined by trust and suspicion and the way Shakespeare's plays, diverse and equivocal as they are, embody the tension between the trustful and the suspicious outlook. Having fulfilled its primary aim of demonstrating Josipovici's originality of thought and revealing the consistency with which the ideas of trust and suspicion recur throughout his writing career, the present study will proceed in this short conclusion to foreground the import of Josipovici's stance for the present-day intellectual and artistic activity. It is worth noting that Josipovici's attempt at putting the feelings of trust and suspicion in a diachronic perspective not only relates to Febvre's distant appeal or the major expansion of affect studies in the 1990s but, even more importantly, it 
ties in with the incipient cultural tendencies of the $21^{\text {st }}$ century. When in 2002 Linda Hutcheon declared that "the postmodern moment ha[d] passed" (p. 181), her words only confirmed the emergence of a new post-postmodernist frame of mind, which Madhu Dubey describes as "marked by a renewed engagement with the social world" (2011, p. 364). Without interfering with nomenclature, Ihaab Hassan ventured a year later to specify the nature of this inchoate mindset by claiming that "postmodernism expands into geopolitical postmodernity while seeking to become a postmodernism not of suspicion but of trust" (2003, p. 303). It appears thus that the postmodern euphoric acceptance of nihilism, to use Frederic Jameson's (1991, p. 368) words, has been in some measure substituted with a new "structure of feeling" 8 issuing from the long-repressed need for empathy and connectedness. In the context of the overall disinclination towards aleatory practices, ironic detachment and the deconstruction of meaning, detectable in many strands of contemporary art, ${ }^{9}$ Josipovici's hopeful declaration: "I believe that the spirit of suspicion has at some point to yield to the spirit of trust - trust in the material, trust in our abilities, trust in the act of making itself" (1999, pp. 2-3) gains a broader cultural significance. ${ }^{10}$

\footnotetext{
${ }^{8}$ Partaking of Zeitgeist, the phrase was used by Raymond Williams to describe a sensibility or a sentiment that "gives the sense of a generation or a period" (1977, p. 131). It is now employed by the contemporary scholars attempting to capture the cultural spirit of the $21^{\text {st }}$ century and subsume it under the term "metamodernism." In their publication Metamodernism: Historicity, Affect and Depth After Posmodernism, van den Akker and Vermeulen define the metamodern structure of feeling as "an oscillating in-betweenness or, rather, a dialectical movement [...] between [...] post-modern and pre-postmodern [...] predilections: between irony and enthusiasm, between sarcasm and sincerity, between eclecticism and purity, between deconstruction and construction and so forth" (2017, pp. 10-11).

9 Van den Akker and Vermeulen (2017) mention a number of new aesthetic phenomena which endeavour to move beyond postmodern stylistic and formal tactics. They include, among others, the New Romanticism in the arts, the New Mannerism in crafts, the New Aesthetic in design, and the New Sincerity in literature .

${ }^{10}$ This article had been completed and submitted for review before the threat of the coronavirus became worldwide. The current epidemiological situation has made the interplay of trust and suspicion an acutely real aspect of our everyday functioning. Undoubtedly, the relation between those two emotional attitudes has become more problematic and dynamic while the emerging prevalence of trust over suspicion has ceased to be evident. All this, however, makes the trust/suspicion interaction a vital cultural issue and worth further investigation.
} 


\section{SOURCES}

Josipovici, Gabriel. (1982). Writing and the Body. Princeton: Princeton University Press. Josipovici, Gabriel. (1988). The Book of God. New Haven-London: Yale University Press. Josipovici, Gabriel. (1999). On Trust: Art and the Temptation of Suspicion. New Haven-London: Yale University Press.

Josipovici, Gabriel. (2010). What Ever Happened to Modernism? New Haven-London: Yale University Press.

Josipovici, Gabriel. (2016). Hamlet: Fold on Fold. New Haven-London: Yale University Press.

Konstantinou, Lee. (2017). Four Faces of Postirony. In: Robin van den Akker et al. (eds.), Metamodernism: Historicity, Affect, and Depth After Postmodernism (pp. 87-102). LondonNew York: Rowman and Littlefield.

\section{REFERENCES}

Adorno, Theodore. (1974). Minima Moralia: Reflections from a Damaged Life. London: New Left Books.

Van den Akker, Robin, Vermeulen, Timotheus. (2017). Periodising the 2000's, or, the Emergence of Metamodernism. In: Robin van den Akker et al. (eds.), Metamodernism: Historicity, Affect, and Depth After Postmodernism (pp. 1-23). London-New York: Rowman and Littlefield.

Dubey, Madhu. (2011). Post-postmodern realism? Twentieth-Century Literature, 57(3/4), pp. 364-371. Fevbre, Lucien. (1973). Sensibility and history: How to reconstitute the emotional life of the past. In: Peter Burke (ed.), A New Kind of History (pp. 12-26). London: Routledge and Kegan Paul. Harbage, Alfred (ed.). (1977). William Shakespeare: The Complete Works. New York: Viking Press. Hassan, Ihaab. (2003). Beyond Postmodernism: Toward an Aesthetic of Trust. Modern Greek Studies, 11 , pp. 303-316.

Hutcheon, Linda. (2002). The Politics of Postmodernism. London-New York: Routledge.

Jameson, Fredric. (1991). Postmodernism, or, the Cultural Logic of Late Capitalism. London-New York: Verso.

Lang, Johannes. (2018). New Histories of Emotions. History and Theory, 1, pp. 104-120.

Langer, Lawrence L. (1995). Admitting the Holocaust. Oxford: Oxford University Press.

Massumi, Brian. (2002). Parables for the Virtual. Durham-London: Durham University Press.

Nietzsche, Friedrich. (1974). The Gay Science. Trans. Walter Kaufman. New York: Vintage Books.

Rosenwein, Barbara H. (2002). Worrying about Emotions in History. The American Historical Review, 107(3), pp. 821-845.

Williams, Raymond. (1977). Marxism and Literature. Oxford: Oxford University Press.

Article submission date: 21.11.2019

Date qualified for printing after reviews: 06.04.2020 